\title{
TISSUE MAST CELLS IN THE BONE MARROW IN RHEUMATOID ARTHRITIS
}

\author{
BY \\ P. C. MCCREA \\ Royal City of Dublin Hospital, and Department of Pathology, Trinity College, Dublin
}

Mast cells are connective tissue cells of the histiocytic family. They are characterized by the presence of large cytoplasmic granules which stain metachromatically with dyes such as toluidine blue, in which respect they resemble blood basophils. Tissue mast cells are present in the connective tissue of many species, especially in the walls of blood vessels and the immediate adjacent connective tissue (Brit. med. J., 1956).

The significance of tissue mast cells in human bone marrow is uncertain. Rohr (1949) found tissue mast cells in the bone marrow in hypoplastic and aplastic conditions only. Fadem (1951), in a study of 2,800 cases, found mast cells in seven cases, three of which showed severe marrow depression. Williams (1952) and Johnstone (1954), who examined marrows from patients suffering from a wide variety of pathological conditions, found mast cells in 17 and 70 per cent. respectively. Two of the patients in Johnstone's series suffered from rheumatoid arthritis, although in one of them the disease was classified as atypical. Mast cells were demonstrated in both cases and were present in unusually large numbers in the atypical case.

The purpose of the present investigation was to study the mast cell content of the bone marrow in patients suffering from active rheumatoid disease and anaemia. These patients formed part of a group in which the relationship between marrow iron content and response to intravenous iron therapy had been investigated previously (McCrea, 1958). It was possible, therefore, as a supplementary study, to determine whether the presence or absence of mast cells from the bone marrow was of prognostic significance regarding the effect of intravenous iron therapy.

\section{Materials and Methods}

Twelve in-patients suffering from active rheumatoid arthritis and a moderate degree of anaemia were examined. In each case the initial haemoglobin level was less than $11 \cdot 2 \mathrm{~g} . / 100 \mathrm{ml}$. (70 per cent.). In an earlier investigation of bone marrow iron content (McCrea, 1958), sternal marrow was aspirated from these patients and histological sections were prepared, using a modification (Hutchison, 1953) of the technique described by Cappell, Hutchison, and Smith (1947). Further sections were prepared from the same blocks and were stained with 0.01 per cent. toluidine blue to demonstrate mast cells. Tissue mast cells and basophil leucocytes both contain granules with metachromatic staining properties, but Johnstone (1954) has pointed out that the granules of the latter cells are extremely soluble in water and alcohol and are, therefore, not seen in fixed tissue sections when an aqueous or alcoholic fixative has been used.

Mast cells are usually rounded or ovoid, although bizarre forms with elongated cytoplasmic processes are sometimes seen. The granules often overlay the nucleus tending to obscure it (Johnstone, 1954). In each case, several marrow fragments were examined microscopically for mast cell content and the marrows were roughly classified as follows:

$$
\begin{aligned}
& \text { - } \quad \text { No mast cells present. } \\
& +\quad \text { Scanty mast cells present but not more than }
\end{aligned}
$$

\section{Results}

Marrow mast cells were reasonably plentiful in one patient (Case 6), scanty mast cells were present in five cases, and in the remaining six, no mast cells were demonstrated (Table, overleaf). Mast cells, when present, were irregularly distributed throughout the marrow fragments and sometimes a mast cell was present in one fragment, whereas another fragment of the same marrow contained no mast cells. 
TABLE

FINDINGS IN STERNAL MARROW IN TWELVE CASES

\begin{tabular}{c|c|c|c}
\hline $\begin{array}{c}\text { Case } \\
\text { No. }\end{array}$ & $\begin{array}{c}\text { Tissue } \\
\text { Mast Cells }\end{array}$ & $\begin{array}{c}\text { Marrow } \\
\text { Iron }\end{array}$ & $\begin{array}{c}\text { Response to } \\
\text { Intravenous Iron } \\
\text { Therapy* }\end{array}$ \\
\hline $\mathbf{1}$ & + & + & - \\
\hline $\mathbf{2}$ & + & + & - \\
\hline $\mathbf{3}$ & + & + & - \\
\hline $\mathbf{4}$ & + & + & - \\
\hline $\mathbf{5}$ & + & + & - \\
\hline $\mathbf{6}$ & ++ & - & + \\
\hline $\mathbf{7}$ & - & - & + \\
\hline $\mathbf{8}$ & - & - & + \\
\hline $\mathbf{9}$ & - & + & - \\
\hline 10 & - & + & - \\
\hline 11 & - & + & - \\
\hline 12 & - & + & - \\
\hline
\end{tabular}

* Increase in haemoglobin of at least $2 \mathrm{~g}$. per $100 \mathrm{ml}$. over a test period of one month.

There was no constant relationship between the presence or absence of marrow mast cells, marrow iron content, and response of the anaemia to intravenous iron therapy (Table). Mast cells were demonstrated both in marrows which contained iron and in those which did not. Conversely, in some marrows which contained iron and in some which were devoid of iron, no mast cells were seen. The anaemia in one patient (Case 6) in which marrow mast cells were most plentiful responded to iron therapy. Cases refractory to iron therapy included a number whose marrows contained mast cells and some whose marrows showed no mast cells. The anaemia in two cases, in which neither marrow mast cells nor marrow iron were demonstrated, improved after iron therapy (Table).

\section{Discussion}

Mast cell granules contain heparin (Jorpes, 1946) and there is strong evidence that the granules contain histamine as well (Riley and West, 1953). Rohr (1949) and Fadem (1951) suggested that the presence of mast cells in the bone marrow indicated marrow depression in some form. Fadem felt that the marrow inhibition was partly due to the inhibitory effect of heparin upon local cell growth, and concluded that tissue mast cells are abnormal constituents of bone marrow. Johnstone (1954), however, who examined a large number of patients suffering from a wide variety of pathological conditions, considered that mast cells were a normal constituent of human bone marrow and that their absence in 30 per cent. of his cases was probably governed by the selection inevitable in a small sample of marrow. Riley (1959) felt that tissue mast cells in human bone marrows had the same significance as elsewhere, and that they were a normal constituent of the connective tissues.

Johnstone (1954) examined two cases of rheumatoid arthritis. Mast cells were present in the marrow in each case and in one, which was classified $\bar{\sigma}$ as atypical rheumatoid, mast cells were present in unusually large numbers. Mast cell proliferation to this degree was not seen in the present series and, indeed, mast cells were scanty or absent in all but one of the marrows examined.

Johnstone (1954) was unable to find any correlation between the iron content of the marrow and the presence or numbers of mast cells there. The results of the present study agree with Johnstone's observations in this respect. The presence or absence of mast cells from the bone marrow was of no value in forecasting the results of intravenous iron therapy. 옥 The anaemia in Case 6 responded to intravenous iron therapy though marrow mast cells were most plentiful, and cases refractory to iron therapy included some whose marrows contained mast cells and some whose marrows contained none.

Marrow mast cells were not demonstrated in hab of the cases studied. Their absence may possible have been due to a sampling error on account of the small pieces of tissue examined. The presence or absence of mast cells is not related to marrow iron content or to the success or failure of intravenous iron therapy. It would appear that the presence of these cells in small numbers or their absence from marrow samples in anaemic patients with rheumatoid arthritis is of little significance.

\section{Summary}

Sternal bone marrows from twelve patients suffering from active rheumatoid arthritis and anaemia were examined for mast cell content.

In five cases scanty mast cells were present, in one the marrow contained a moderate number of mast cells, and in six no mast cells were demonstrated.

There was no constant relationship between the of presence or absence of marrow mast cells, marrow N iron content, and response of the anaemia to intravenous iron therapy.

I am grateful to the medical staff of the Royal Bath Hospital, Harrogate, where this study was undertaken, $\mathscr{Q}$ for their co-operation. Dr. J. V. Wilson was most helpful, and Mr. H. Gibson, F.I.M.L.T., gave valuable technical assistance. 


\section{REFERENCES}

Brit. med. J. (1956). 2, 219.

Cappell, D. F., Hutchison, H. E., and Smith, G. H. (1947). Ibid., 1, 403.

Fadem, R. S. (1951). Blood, 6, 614.

Hutchison, H. E. (1953). Ibid., 8, 236.

Johnstone, J. M. (1954). J. clin. Path., 7, 275.

Jorpes, J. E. (1946). "Heparin in the Treatment of Thrombosis", 2nd ed. Oxford University Press, London.

McCrea, P. C. (1958). Ann. rheum. Dis., 17, 89.

Riley, J. F. (1959). "The Mast Cells". Livingstone, Edinburgh and London.

and West, G. B. (1953). J. Physiol. (Lond.), $120,528$.

Rohr, K. (1949). Blood, 4, 130.

Williams, G. T. (1952). Amer. J. clin. Path., 22, 1039.

Mastzellen tissulaires dans l'os des malades atteints d'arthrite rhumatismale

RÉSUMÉ

La moelle osseuse du sternum fut examinée chez douze malades atteints d'arthrite rhumatismale évolutive accompagnée d'anémie pour y rechercher des mastzellen.

Dans cinq cas on trouva quelques mastzellen, dans un cas on en trouva quelques-unes et dans six cas on n'en trouva aucune.

On ne trouva aucun rapport constant entre la présence ou l'absence des mastzellen dans la moelle osseuse et la teneur en fer de la moelle et la réponse de l'anémie à la thérapie martiale intraveineuse.

Mastocitos tisulares en la médula ósea de enfermos con artritis reumatoide

\section{SUMARIO}

Médula ósea del esternón fué examinada en doce enfermos con artritis reumatoide evolutiva, acompañada de anemia, para estudiar su contenido en mastocitos.

En cinco casos se encontraron mastocitos escasos, en uno se vió un número moderado de ellos y en seis casos no se encontró mastocito alguno.

No hubo relación constante entre la presencia o ausencia de mastocitos en la médula ósea por un lado y el contenido de hierro en la médula y la respuesta de la anemia a la ferroterapia intravenosa por el otro. 